\title{
Penile Anthropometry of Healthy Turkish Children Aged One to Twenty-Four Months
}

\section{1-24 Ay Arası Sağlıklı Türk Çocuklarının Penil Antropometrileri}

\author{
Atilla Çifci ${ }^{1}$, Mehmet Boyraz ${ }^{2}$ \\ ${ }^{1}$ Ankara Yıldırım Beyazıt University, Faculty of Medicine, Department of Pediatrics \\ ${ }^{2}$ Ankara Ylldırım Beyazıt University, Faculty of Medicine, Department of Pediatric Endocrinology
}

\begin{abstract}
Objectives: To establish a normal range of penile anthropometric parameters of infants younger than two years based on their age.

Materials and Methods: A total of 573 infants younger than two years were included in our study. Penile length and circumference were measured and the percentiles were established according to infants age. Variations of penile anthropometry in relation to age and another anthropometric parameters were evaluated using multiple linear regression models.

Results: The mean stretched penile length \pm SD and mean penile circumference \pm SD of all infants aged 1to 24 months were $38.82 \pm 8.38$ and $14.81 \pm 3.09 \mathrm{~mm}$ respectively. Stretched penile length and circumference were affected by age, body weight and length ( $\mathrm{p}=0.001)$.

Conclusion: This study provides reference values of stretched penile lengths and circumference for Turkish infants younger than 24 months. Our findings suggest that penile measurement abnormalities during routine healthy children examination may be a clue helping in detecting congenital or endocrine disorders.

Key words: Stretched penile circumference, stretched penile length, Turkish infants, reference values
\end{abstract}

\section{$\ddot{O ̈ z}$}

Amaç: 2 yaș altındaki infantlarda; yaş gruplarına göre normal penil antropometrik ölçümlerin değerlendirilmesi amaçlanmıștır.

Materyal ve Metot: Bu çalışmaya 2 yaş altı toplam 573 hasta alındı. Penis uzunluğu ve çapı ölçülerek yaşa göre persantiller belirlendi. Çoklu lineer regresyon modelleri kullanılarak yaşa göre penil antropometri değişkenleri ve diğer antropometrik ölçümler değerlendirildi.

Bulgular: 1-24 ay arası çocuklarda sırasıyla, gergin penil uzunluk \pm SD $38,82 \pm 8,38$ ve penil çap \pm SD

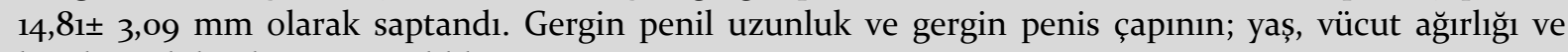
boydan etkilendiği tespit edildi.

Sonuç: Bu çalışmada 24 aylıktan küçük Türk çocuklarının gergin penil uzunluk ve çap için referans değerleri belirlenmiștir. Bulgularımız rutin sağlam çocuk muayenesi sırasında doğuștan veya endokrin bozuklukların bir ipucu olabilecek penil ölçüm anormalliklerinin tespit edilmesine yardımcı olabileceğini göstermiștir.

Anahtar Kelimeler: Gergin penil çap, Gergin penil uzunluk, Türk çocukları, referans değerler

\section{Yazıșma Adresi / Correspondence:}

Dr. Atilla Çifci

e-mail: dratillacifci@gmail.com

Date of submission: 05.03.2019

Date of admission: 12.03.2019

\section{Introduction}

Examination of male external genitalias is an important step during well child visits. Abnormalities in the penile anthropometry might be the first sign of growth hormone deficiency, hypopituitarism, congenital or other endocrine disorders. Early diagnosis and treatment is essential to prevent potential consequences ${ }^{1}$. 
Penile anthropometry is reported to vary between different countries ${ }^{2-9}$. Establishment of reference values in each country based on anthropometric measures of the children is important step for early diagnosis and treatment of potential congenital diseases ${ }^{10-11}$.

We aimed to determine the penile anthropometry and estimate correlation with age and other anthropometric parameters of normal Turkish infants aged between 1 and 24 months.

\section{Materials and Methods}

This study was carried out at Department of Well Child of Ankara Yıldırım Beyazit University between June 2018 and December 2018. Patients eligible for this study were male infants aged between 1 and 24 months that applied to the well child unit for routine examination. Patients with major congenital malformations, chromosomal anomalies, genital anomalies and endocrine disorders were excluded from this study. The study was approved by the Ethics Committee of Ankara Yıldırım Beyazıt University, Yenimahalle Training and Research Hospital Ethics Committee of Clinical Research. Written informed consent was obtained from the parents of the included patients.

All measurements were performed in a warm $\left(23-24^{\circ} \mathrm{C}\right)$ and comfortable room. Penile length and circumference were determined by the method described by Cinaz ${ }^{1}$. Measurements were taken in a supine position with both legs in a flexed position. Fat tissue over the pubic ramus was maximally compressed by a flexible plastic ruler and the penis was stretched by holding the glans between the two fingers of the examiner. The distance between the base of the penis and the tip of the glans was measured as the penile length. Penis circumference was measured by paper ruler, the middle of loose penis was measured, and recorded.

Two consecutive measurements were taken by the author (Cifci A) to the nearest millimeter and the mean was recorded. Body weight, length, and head circumference of the patients were also measured. Length was measured in the supine position, and weight was measured with a scale sensitive to $10 \mathrm{~g}$. All measurements were recorded.

\section{Statistical Analysis}

Data were analyzed using by IBM SPSS Statistics 21.0 (IBM Corp. Released 2012. IBM SPSS Statistics for Windows, Version 21.o. Armonk, NY: IBM Corp.). Continuous variables were reported by both mean \pm standard deviation (SD), median, and, minimum (min)-maximum ( $\max$ ) values. The 3 rd, $5^{\text {th }}$, 1oth, 25th, 5oth, $75^{\text {th }}$, 9oth, 95th and 97th percentile values were calculated for penile length and circumference measurements. The Spearman's correlation coefficient was used to determine the presence of a linear relationship between penile anthropometry and gestational age, gestational weight, current age, current body weight, and current height. Multivariate linear regression analysis was used to explore the variables that influenced penile anthropometry. A p-value less than 0.05 were accepted to be statistically significant.

\section{Results}

A total of 573 male infant were included in our study. The mean stretched penile length \pm SD and mean penile circumference \pm SD of 12 and 24 months infants were $38.27 \pm 5.31,16.23 \pm 2.86$, and $47.05 \pm 6.29$ and $14.05 \pm 2.87 \mathrm{~mm}$ respectively. The mean stretched penile length \pm SD and mean penile circumference \pm SD of all infants aged 
1to 24 months were $38.82 \pm 8.38$ and $14.81 \pm 3.09 \mathrm{~mm}$ respectively. The $3^{\text {rd }}, 5^{\text {th }}, 10^{\text {th }}, 25^{\text {th }}$, $50^{\text {th }}, 75^{\text {th }}, 90^{\text {th }}, 95^{\text {th }}$ and $97^{\text {th }}$ percentile values of the stretched penis length $(\mathrm{mm})$ and the stretched penis circumference $(\mathrm{mm})$ according to age are depicted in Table 1 and Table 2 respectively. The percentile values of the stretched penis length $(\mathrm{mm})$ and the stretched penis circumference $(\mathrm{mm})$ according to age are demonstrated in Figure 1 and Figure 2 respectively.

Table 1. Stretched Penis Length (mm) Percentiles (p) According to Age (months).

\begin{tabular}{|c|c|c|c|c|c|c|c|c|c|}
\hline \multirow{2}{*}{ Age } & \multicolumn{8}{|c|}{ Stretched Penis Length (mm) Percentiles (p) } \\
\cline { 2 - 11 } & $\mathbf{3}$ & $\mathbf{5}$ & $\mathbf{1 0}$ & $\mathbf{2 5}$ & $\mathbf{5 0}$ & $\mathbf{7 5}$ & $\mathbf{9 0}$ & $\mathbf{9 5}$ & $\mathbf{9 7}$ \\
\hline $\mathbf{1}$ & $\mathbf{2 2}$ & $\mathbf{2 4}$ & $\mathbf{2 6}$ & $\mathbf{2 8}$ & 31 & 36 & 40 & 43 & 45 \\
\hline 2 & 18 & $\mathbf{2 2}$ & $\mathbf{2 5}$ & $\mathbf{2 7}$ & 31 & 35 & 40 & 42 & 45 \\
\hline 3 & 20 & 21 & 26 & 29 & 31 & 35 & 40 & 49 & 50 \\
\hline 4 & 21 & 22 & 23 & 25 & 28 & 32 & 37 & 41 & 43 \\
\hline 5 & 21 & 21 & 22 & 24 & 31 & 35 & 41 & 45 & 48 \\
\hline 6 & 21 & 21 & 24 & 27 & 30 & 36 & 39 & 41 & 47 \\
\hline 7 & 19 & 20 & 23 & 26 & 31 & 35 & 41 & 45 & 55 \\
\hline 8 & 24 & 26 & 27 & 30 & 33 & 38 & 44 & 46 & 55 \\
\hline 9 & 22 & 27 & 29 & 33 & 36 & 39 & 43 & 46 & 50 \\
\hline 10 & 29 & 30 & 31 & 31 & 35 & 38 & 42 & 50 & 55 \\
\hline 11 & 27 & 31 & 31 & 34 & 37 & 40 & 44 & 44 & 50 \\
\hline 12 & 20 & 22 & 26 & 33 & 36 & 40 & 42 & 43 & 44 \\
\hline 13 & 25 & 28 & 31 & 38 & 42 & 46 & 49 & 49 & 55 \\
\hline 14 & 35 & 36 & 36 & 42 & 44 & 47 & 49 & 50 & 51 \\
\hline 15 & 18 & 21 & 26 & 33 & 43 & 47 & 48 & 49 & 51 \\
\hline 16 & 25 & 37 & 37 & 41 & 43 & 46 & 50 & 50 & 51 \\
\hline 17 & 42 & 43 & 43 & 45 & 47 & 48 & 51 & 52 & 52 \\
\hline 18 & 32 & 36 & 37 & 38 & 41 & 44 & 49 & 52 & 53 \\
\hline 19 & 37 & 39 & 39 & 41 & 43 & 46 & 48 & 50 & 51 \\
\hline 20 & 30 & 39 & 40 & 43 & 47 & 52 & 53 & 53 & 53 \\
\hline 21 & 36 & 39 & 40 & 42 & 43 & 46 & 50 & 54 & 56 \\
\hline 22 & 38 & 40 & 42 & 44 & 46 & 49 & 50 & 53 & 56 \\
\hline 23 & 33 & 35 & 40 & 42 & 46 & 50 & 53 & 54 & 55 \\
\hline 24 & 35 & 37 & 38 & 42 & 46 & 49 & 52 & 54 & 55 \\
\hline
\end{tabular}

\section{Discussion}

In this present study we aimed to estimate the anthropometric parameters of the Turkish infants between one and twenty- four months by measuring the stretched penile length (SPL) and circumference (PC) and to calculate their percentiles. We found that the mean SPL \pm SD and PC \pm SD of all infants of all infants aged 1to 24 months were $38.82 \pm 8.38$ and $14.81 \pm 3.09 \mathrm{~mm}$ respectively. 
Differences in penile measurements have been reported by authors from the same countries. There was some differences between the findings of our study and previously reported studies from Turkey ${ }^{1-2,8-10}$. The most comprehensive study from Turkey was conducted by Cinaz et al ${ }^{1}$. They determined the mean penile length and established the percentile curves of 1278 Turkish children from newborn to prepubertal period. They reported that the mean \pm SD of SPL of one and two years old infants were $44.40 \pm 0.69$ and $5.42 \pm 0.62 \mathrm{~mm}$. Another study from Turkey conducted by Halil et al, they measured the SPL of 585 neonate and found that the mean SPL \pm SD of term neonates was $32.00 \pm 5.51 \mathrm{~mm}^{2}$. In our study the mean \pm SD of SPL were $38.27 \pm 5.31$ and $47.05 \pm 6.29 \mathrm{~mm}$ for one and two years old infants respectively. To increase the reliability of our study and to decrease the errors of measurements, all measurements were performed by the author (Cifci A) in a comfortable enviroment for all infants.

Table 2. Stretched Penis Circumference (mm) According to Age (months)

\begin{tabular}{|c|c|c|c|c|c|c|c|c|c|}
\hline \multirow{2}{*}{ Age } & \multicolumn{9}{|c|}{ Stretched Penis Circumference (mm) Percentiles (p) } \\
\hline & 3 & 5 & 10 & 25 & 50 & 75 & 90 & 95 & 97 \\
\hline 1 & 10 & 10 & 11 & 11 & 13 & 16 & 17 & 18 & 21 \\
\hline 2 & 10 & 10 & 11 & 12 & 14 & 16 & 18 & 20 & 22 \\
\hline 3 & 10 & 10 & 10 & 12 & 13 & 15 & 17 & 19 & 21 \\
\hline 4 & 9 & 10 & 10 & 11 & 12 & 15 & 16 & 19 & 20 \\
\hline 5 & 9 & 10 & 10 & 11 & 12 & 14 & 19 & 23 & 25 \\
\hline 6 & 8 & 10 & 10 & 11 & 14 & 16 & 20 & 23 & 24 \\
\hline 7 & 10 & 10 & 10 & 11 & 12 & 15 & 18 & 21 & 28 \\
\hline 8 & 10 & 10 & 10 & 11 & 12 & 14 & 17 & 20 & 22 \\
\hline 9 & 9 & 10 & 10 & 12 & 15 & 17 & 18 & 19 & 21 \\
\hline 10 & 10 & 11 & 11 & 12 & 13 & 16 & 17 & 20 & 21 \\
\hline 11 & 12 & 12 & 12 & 14 & 16 & 18 & 19 & 22 & 22 \\
\hline 12 & 10 & 11 & 12 & 13 & 16 & 18 & 20 & 22 & 23 \\
\hline 13 & 12 & 13 & 14 & 14 & 15 & 16 & 18 & 22 & 22 \\
\hline 14 & 11 & 12 & 14 & 14 & 15 & 16 & 17 & 18 & 21 \\
\hline 15 & 10 & 14 & 14 & 15 & 15 & 16 & 18 & 19 & 21 \\
\hline 16 & 13 & 14 & 14 & 14 & 15 & 16 & 19 & 21 & 28 \\
\hline 17 & 14 & 14 & 15 & 15 & 16 & 17 & 19 & 20 & 20 \\
\hline 18 & 10 & 11 & 11 & 11 & 13 & 14 & 15 & 17 & 18 \\
\hline 19 & 11 & 11 & 12 & 13 & 14 & 15 & 17 & 19 & 19 \\
\hline 20 & 10 & 11 & 11 & 12 & 13 & 14 & 15 & 15 & 18 \\
\hline 21 & 11 & 12 & 12 & 12 & 13 & 14 & 15 & 18 & 20 \\
\hline 22 & 11 & 12 & 13 & 14 & 15 & 17 & 18 & 20 & 21 \\
\hline 23 & 10 & 11 & 11 & 12 & 13 & 14 & 18 & 19 & 20 \\
\hline 24 & 11 & 12 & 13 & 14 & 15 & 16 & 18 & 20 & 21 \\
\hline
\end{tabular}


Recent studies from different countries showed that the penile length values varies according to geographical areas, countries and ethnic origin of the infants. Different studies in this field found that the mean penile lengths was $32 \mathrm{~mm} \mathrm{~cm}$ in Iranians, 30.60 $\mathrm{mm}$ in Japanese infants and $34 \mathrm{~mm}$ in Egyptian new born males 3,5,7.

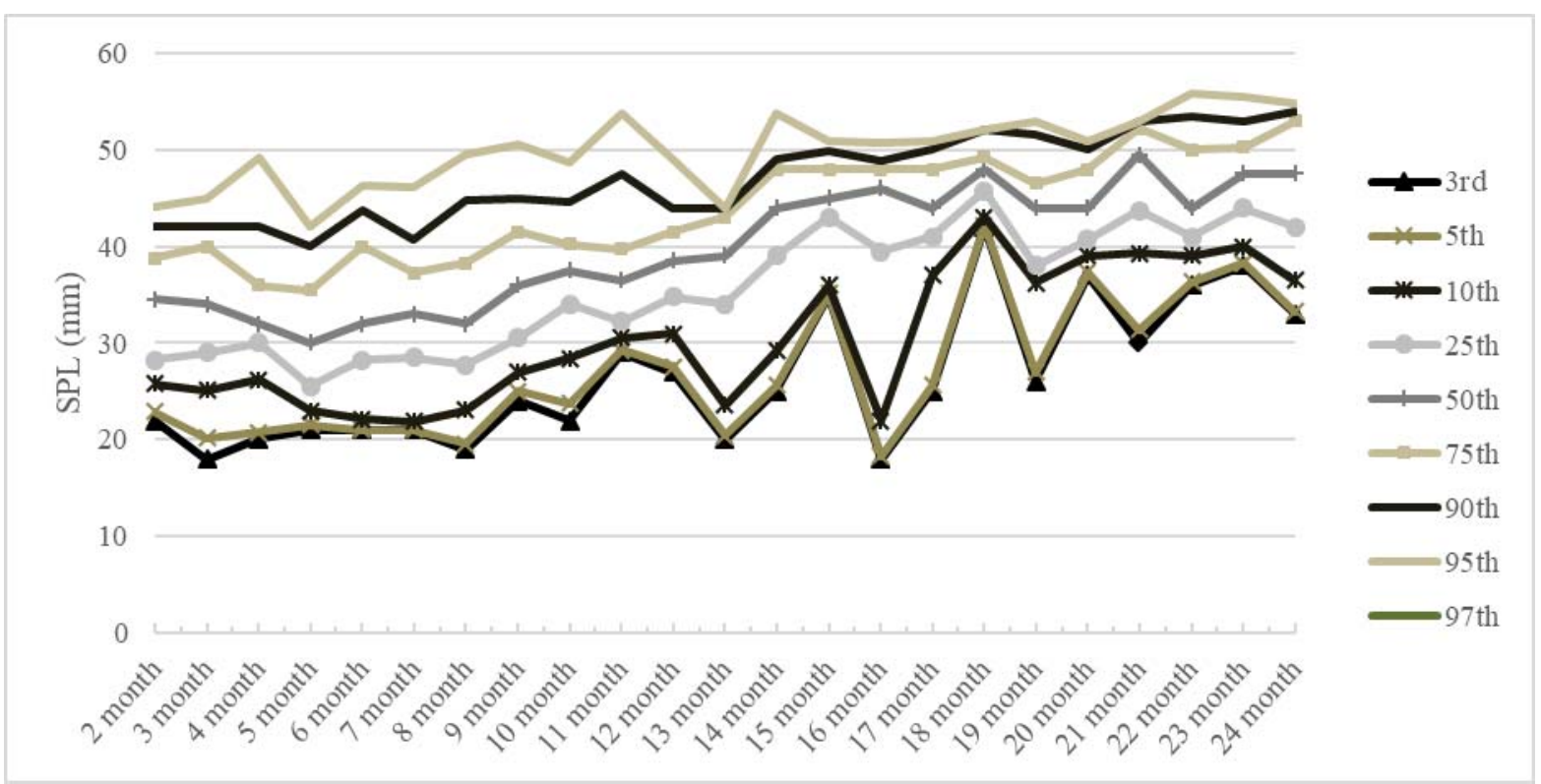

Figure 1. Stretched Penis Length Percentiles According to Age.

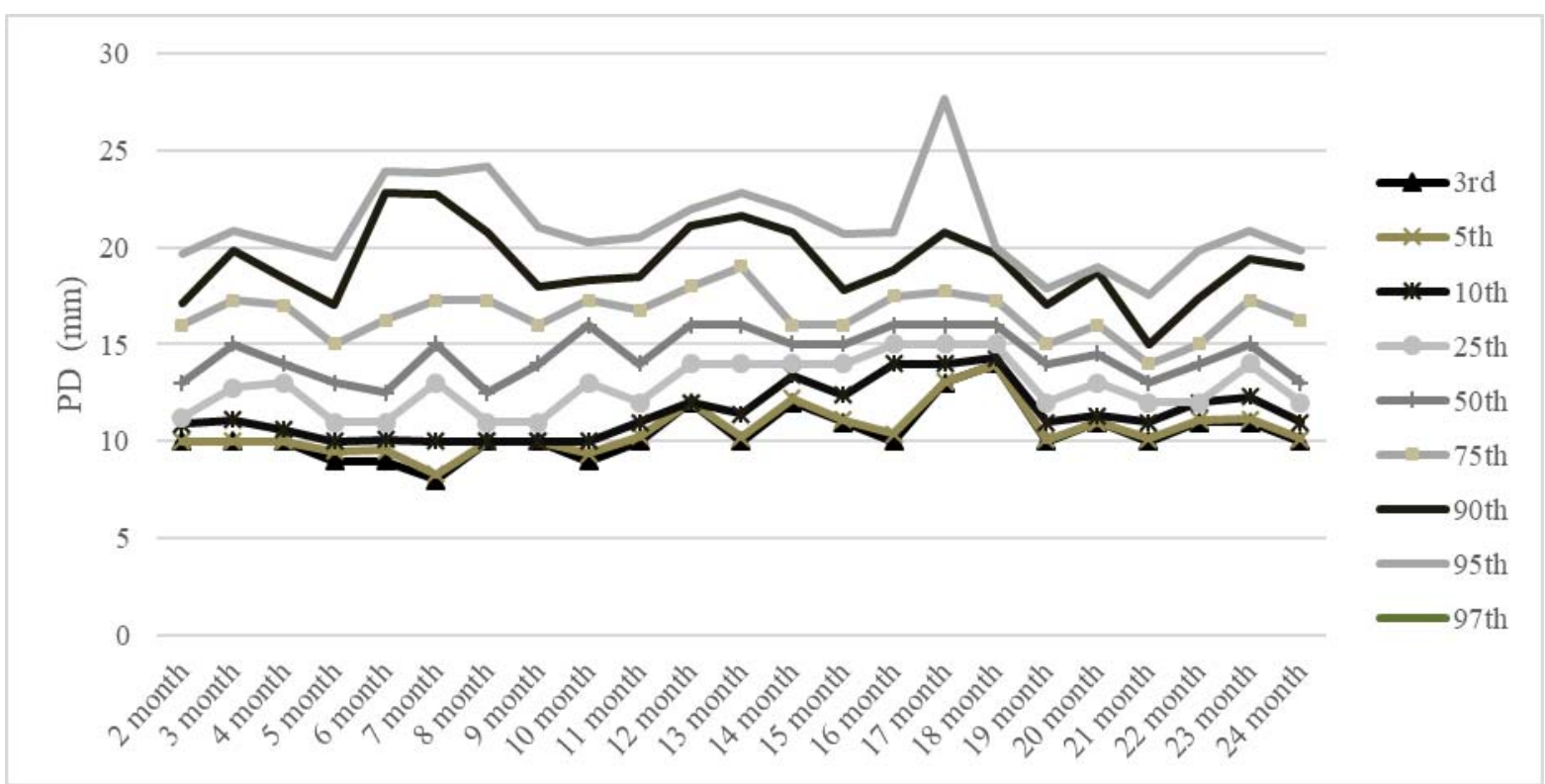

Figure 2. Stretched Penis Circumference Percentiles According to Age.

Multivariate regression analysis of our study showed that SPL and PC were affected by anthropometric measurements like age, body weight and length in infants. Different studies from our country investigated the correlation between SPL and the anthropometric measurements of children ${ }^{1,8-9}$. Cinaz et al reported a significant relation between SPL and age, height, body weight and height age in all children ${ }^{1}$. Kutlu et al concluded that SPL was positively correlated with height and head 
circumference of all children included in their study. Whereas, Akın et al found only a correlation between SPL and body height ${ }^{8-9}$.

Early recognition of penile disorders is important. Since, it may be the first sign of endocrine disorders that require early diagnosis, further investigation and prompt treatment ${ }^{1-2,10-11}$. In our present study, we included 573 Turkish infants younger than 24 months. We established a normative data for the SPL and PC of the study group and calculated the $3 \mathrm{rd}, 5^{\mathrm{th}}$, 10th, 25th, 5oth, 75th, 9oth, 95th and 97th percentile of the SPL and PC of all infants according to their age. We also estimate a correlation between SPL and PC and other anthropometric measurements of the infants. Our findings may help the professionals to recognize penile size abnormalities during the routine well child examination that might be a clue of congenital or endocrine disorders.

\section{References:}

1. Cinaz P, Yeşilkaya E, Onganlar YH, Boyraz M, Bideci A, Camurdan O , Karaoğlu AB . Penile anthropometry of normal prepubertal boys in Turkey. Acta Pediatric 2012 ;101:e33-6.

2. Halil H, Oğuz ŞS. Normative data for stretched penile length in preterm and term Turkish neonates. Turk J Pediatrics 2017; 59:267-71.

3. Alaee E, Gharib MJ, Fouladinejad M. Penile length and anogenital distance in male newborns from different Iranian ethnicities ingolestan province. Iran Red Crescent Med J 2014; 16:e16729.

4. Bhat A, Upadhyay R, Bhat M, Sabharwal K, Singla M, Kumar V. Penile anthropometry in North Indian children. İndian J Urology 2015;31:106-10.

5. Matsuo N, IshiiT, Takayama JI, MiwaM , HasegawaT. Reference standard of penile size and prevalence of buried penis in Japanese newborn male infants. Endocr J 2014;61:849-53.

6. Park JY, Lim G, Oh KW, et al. Penile length, digit length, and anogenital distance according to birth weight in newborn male infants. Korean J Urol 2015; 56:248-53.

7. El Kholy M, Hamza RT, Saleh M, Elsedfy H. Penile length and genital anomalies in Egyptian male newborns: epidemiology and influence of endocrine disruptors. J Pediatr Endocrinol Metab 2013;26:509-13.

8. Kutlu AO. Normative data for penile length in Turkish newborns. J Clin Res Pediatr Endocrinol 2010;2:107-10.

9. Akin Y, Ercan O, Telatar B, Tarhan F. Penile size in term newborn infants. Turk J Pediatr 2011;53:301-07.

10. Hatipoğlu N, Kurtoğlu S. Micropenis: etiology, diagnosis and treatment approaches. J Clin Pediatr Endocrinol 2013; 5:217-23.

11. Cimador M, Catalano P, Ortolano R, Giuffrè M. The inconspicuous penis in children. Nat Rev Urol 2015;12:205-15. 